\title{
SOUČASNÉ POZNATKY O PODOBĚ CISTERCIÁCKÉHO KLÁŠTERA VE VIZOVICÍCH
}

\author{
ZDENĚK SCHENK - ZDENĚK VÁCHA - RADIM VRLA
}

\begin{abstract}
Abstrakt: Studie shrnuje poznáni o zaniklém středověkém cisterciáckém klášteře Rosa Mariae - Smilheim ve Vizovicích (okr. Zlín) ve světle nových zjištění, učiněných v rámci stavebně-historického prüzkumu a též archeologického výzkumu po roce 2013. Od doby posledniho pojednáník tomuto tématu (2002) byly též publikovány nové historické studie ke klášteru a lokalitě, jež mohly být nyní konfrontovány s aktuálními nálezy, učiněnými v souvislosti s dílčimi opravami stávajicího zámeckého areálu (zejména vnějšich fasád jižního kř́lla zámku), jenž je situován v místě středověkého kláštera. Ukazuje se, že rozsáhlé nálezy kamenných článků pocházejí, stejně jako již známé kusy, z doby budování kláštera po roce 1261. Byl rovněž proveden pokus o hypotetickou rekonstrukci situace klášterního kostela na základě zjištěných archeologických situaci a per analogiam.
\end{abstract}

Klíčová slova: Vizovice - Rosa Mariae - Smilheim - klášter-cisterciáci-středověk.

\section{Latest findings about the form of the Cistercian monastery in Vizovice}

Abstract: This study sums up the information about the medieval Cistercian monastery Rosa Mariae - Smilheim in Vizovice (Zlin district) in the light of new findings produced by building and historical research and archaeological research after 2013. Since the last work on the subject (2002), new historical studies devoted to the monastery and the location have been published, which could be compared with the latest finds made in connection with the repairs of the chateau complex (especially the frontages of the south wing) that now occupies the site of the former medieval monastery. It turns out that the multiple finds of stone elements come, as well as the previously excavated ones, from the period when the monastery was constructed, after the year 1261. The research involved an attempt at a hypothetical reconstruction of the location of the monastery church on the basis of archaeological contexts and per analogiam.

Key words: Vizovice - Rosa Mariae - Smilheim - monastery - Cistercians - Middle Ages.

O pozůstatcích téměř zapomenutého cisterciáckého kláštera ve Vizovicích bylo již na stránkách tohoto sborníku stručně referováno (Kohoutek-Vácha-Vrla 2002, 426-431). V následujícím období, v rámci poměrně rozsáhlých sanačních prací v těsném okolí zámku, byly získány další cenné informace (Archaia Olomouc, o.p. s. 2008; 2009). Byla zde dokumentována řada doposud neznámých architektonických detailů vyzvednutých z výkopů či zachycených ve spodních partiích zdiva jižního zámeckého kř́́dla (Vrla 2013-2014; 2019). Z architektury samotné potom mohly být dále dokumentovány pozůstatky starších zdiv zachycené mimo plochu stavby dnešního zámku. Dalším pramenem informací byla dokumentace archeologických situací v liniových výkopech v okolí zámecké stavby (obr. 1, obr. 15).

Výsledky výše uvedených průzkumů přinesly další významné poznatky o středověkém klášteru, rozsah poznání zde však neustále nedosahuje šíře potřebné $\mathrm{k}$ formulování zásadních tezí k jeho stavební podobě; tento př́íspěvek sumarizuje stavebně-historické a archeologické informace ze zmíněných průzkumů a výzkumů a v závěru podává jejich pracovní interpretaci.

\section{Průzkumy po roce 2013}

V roce 2013 došlo k sejmutí poškozených omítek trnože vnějších fasád jižního křídla zámku do výšky ca 2,5 m nad terénem. V obnažené části zdiva bylo dokumentováno 101 architektonických detailů, druhotně použitých v mladším zdivu zámku (obr. 2). Jeden z prvků (jde o hlavici klenební př́pory[?] s pozůstatky reliéfního vegetabilního dekoru - viz níže) byl ze zdiva vyjmut a uložen v depozitáři zámku. Ostatní prvky byly ponechány na místě a dokumentovány pouze z přístupné strany. Část z nich je tvořena značně poškozenými, téměř amorfními bloky s pozůstatky opracovaných ploch, další část nese na svých zkoumatelných částech původní tvarosloví. 


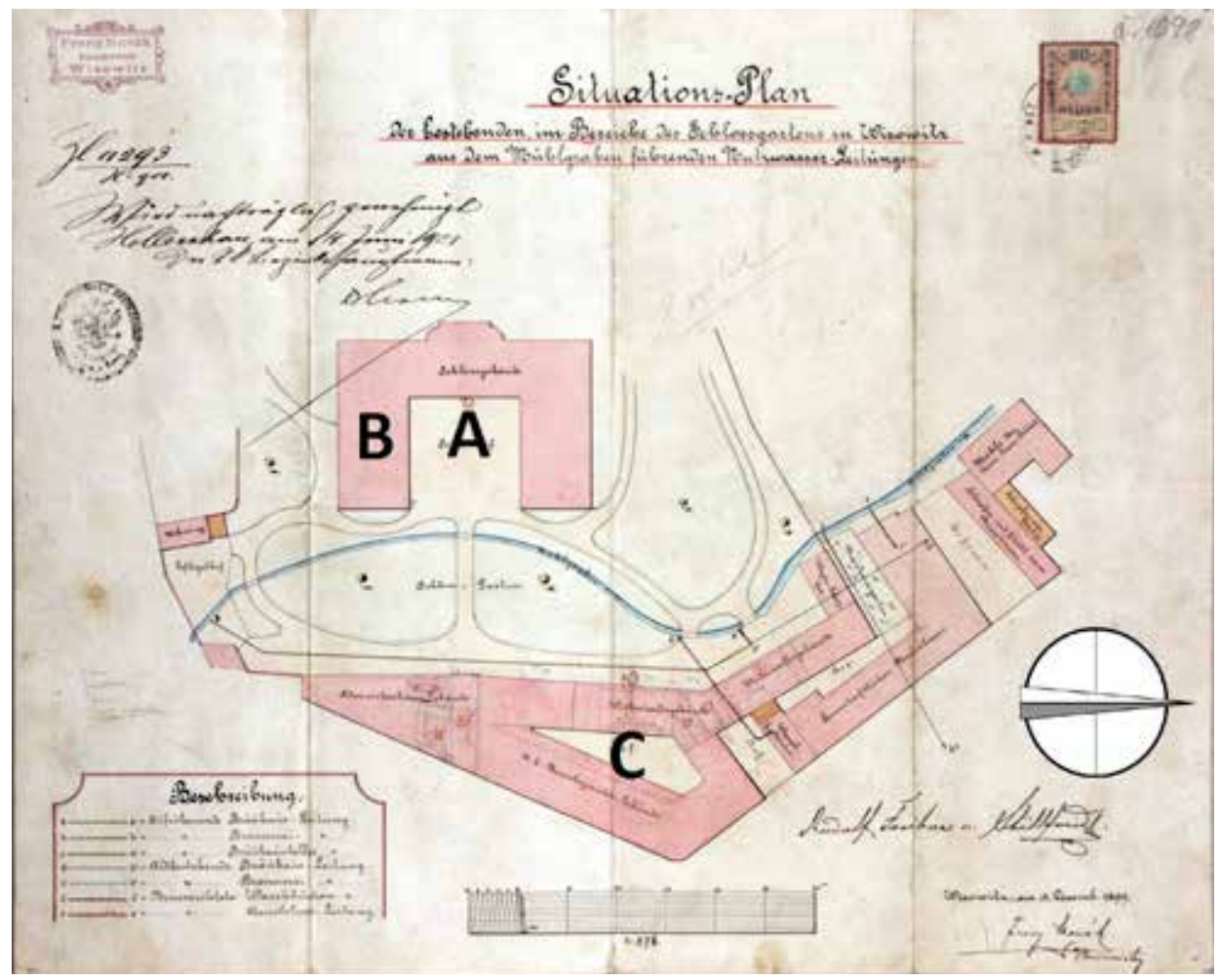

Obr. 1. Vizovice. Půdorysný plán zámeckého areálu z roku 1899 s vyznačením jednotlivých částí zmíněných v textu. A - zámek, B - jižní křídlo zámku, C - předzámčí. Zdroj archiv SZ Vizovice, úprava R. Vrla, 2019.

Abb. 1. Vizovice. Grundrissplan des Schlossareals aus dem Jahr 1899 mit Kennzeichnung der einzelnen im Text erwähnten Teile. A - Schloss, B - Südflügel des Schlosses, C - Vorschloss. Quelle Archiv Staatl. Schloss Vizovice, Bearbeitung R. Vrla, 2019.

V následné fázi průzkumu bylo dokumentováno dalších 29 architektonických prvků, jež se nacházejí na více místech areálu státního zámku Vizovice. Prvky jsou volně loženy a k jejich získání došlo v různých obdobích při stavebních a terénních úpravách zámku a v jeho okolí. ${ }^{1}$ Oproti předchozímu průzkumu, kdy mohly být dokumentovány pouze odhalené plochy prvků ve fasádě, bylo nyní možno provést dokumentaci úplnou.

Další průzkumy, týkající se architektonických prvků středověkého původu, jsou zaměřeny na povrchy zdiv zámeckých sklepů, kde jsou př́istupné líce dalších bloků. Při rekonstrukci opěrné zídky parku, západně od zámku, bude možno detailně dokumentovat i další soubor architektonických článků, zčásti operativně dokumentovaný již v dřívějším období (Kohoutek-VáchaVrla 2002, 429). Veškeré doposud dokumentované kamenné články, vyhotovené z hrubozrnného pískovce, ztotožňujeme s etapou fundace kláštera; nebyly nalezeny znaky, jež by je dovolily řadit do fáze údajné stavební opravy kláštera v roce 1495 (Líbal-Pojsl 1994, 113).

\section{Souhrn poznatků o historii cisterciáckého kláštera Smilheim}

K aktu fundace kláštera Smilem ze Zbraslavi a Stř́lek, brumovským kastelánem, se dochovala listina jako falzum ze 14. století (Šebánek 1951-1952), listina daná v Olomouci 21. srpna

1 Zde je nutno poděkovat zaměstnanci SZ Vizovice, panu Vilému Kolaříkovi, za jeho obětavou snahu o záchranu a shromáždění těchto artefaktů. 


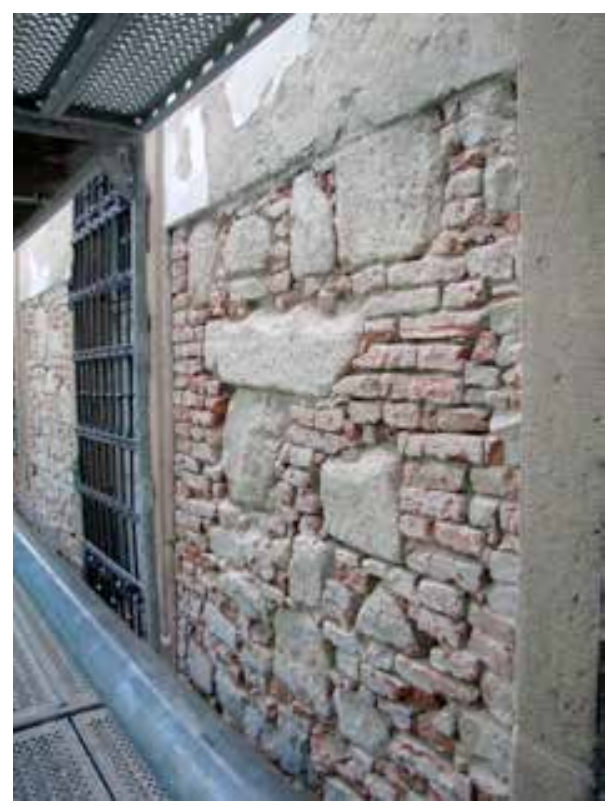

Obr. 2. Vizovice. Část spodní partie jižního průčelí zámku s obnaženou strukturou zdiva; v cihelném zdivu je použito velké množství starších architektonických detailů. Foto R. Vrla, 2013.

Abb. 2. Vizovice. Teil der unteren Partie der Südfassade des Schlosses mit freigelegter Mauerwerksstruktur; im Ziegelsteinmauerwerk wurde eine große Menge älterer architektonischer Details verwendet. Foto R. Vrla, 2013.
1261 (SZA Opava, pob. Olomouc, fond Arcibiskupství Olomouc, listiny, sign. F1 a 2), v níž se mimo jiné hovoří o tom, že Smil založil „(...) Vizovice klášter cisterciáckého ř́du s vůli a štědrou přizni našeho nejvznešenějšího pána Přmysla, zvaného též Otakar, pána Královstvi českého, vévody rakouského a štýrského a markrabète moravského, a se souhlasem ctihodného otce a pána v Kristu, pana Brunona, biskupa olomouckého, v jehož diecézi byl klášter založen. Klášter, nazvaný podle našeho jména Smilheim byl osazen konventem velehradským, pročež jsme jej $v$ souladu s nařizeními cisterciáckého rádu svěrili ctihodnému panu Mikuláši, opatovi velehradskému, jemuž stejně jako jeho ř́ádně ustanoveným nástupcưm se dostává povinnosti visitace a veškerých dalšich práv uvedeného ř́du (...).“2

Jak z listiny plyne, svědky byli ctihodný pan Bruno, biskup olomoucký, Arnold, notár pana vévody, Boreš z Rýzmburka, Smil z Lichtenburka, Vilém z Hustopečí, Vikard z Thürnau, Hartleb, bratr Jenzův, Jiljí ze Švábenic, bratři Beneš, Milota a Ondřej, Kuno z Veveří, maršálek moravský, bratři Smil a Gerhard, synové Bočkovi, Sudomír, komorník břeclavský, Jan z Temenice, Albert z Raškovic, Vojslav, Dubiko, Petr za Slopného a mnozí další.

Je pravděpodobné, dle analogií, že klášter byl míněn také jako Smilovo rodové pohřebiště, byt' sám neměl potomky (Borovský 2011, 16).

Po necelé polovině století existence však byl roku 1314 Smilheim vypleněn Matúšem Č́aem (Peřinka 1907, 76); Jindřich z Lipé, tehdy již držitel zakladatelských práv, proto žádal $\mathrm{v}$ roce 1326 generální kapitulu o svolení k přeložení kláštera na jiné místo, k čemuž však nedošlo (Borovský 2005, 171-172). Po období hospodářského útlumu - hospodářské poměry se zhoršily v letech 1361-1368, kdy se okolní šlechta, zejména páni ze Šternberka (Borovský 2005, 172) spolu s klášterními many, pokoušela zabrat klášterní statky (Plaček-Futák 2006, 96) - klášter prakticky zanikl v průběhu husitských válek. Dle staršího názoru Františka Vácslava Peřinky byl klášter vážně postižen v roce 1418, opět pleněním ,šlechty okolni"“ (Peřinka 1906, 83), a patrně zejména roku 1424, kdy se v něm měl opevnit prchající přívrženec husitů Boček z Kunštátu před vojsky olomouckého biskupa Jana Železného (Peřinka 1907, 83). ${ }^{3}$ Dnešní stav poznání se

2 Překlad Mgr. Richarda Psíka, Ph.D., publikovaný na http://www.mestovizovice.cz/turista/historie-mesta/zakladaci-listina/.

Text zakládací listiny (CDB V/1, 431-436 č. 290) zní (výn̆atek): In nomine sancte trinitatis et individue unitatis amen. Nos Zmilo de Strielcz, castellanus perpetuus ${ }^{a}$ Brunowensis (...). quod nos Zmilo, castellanus de Brunow, una cum Bohublast, nostra coniuge predilecta, unaninini ${ }^{b}$ deliberacione prehabita peccata nostra more fidelium redimere cupientes, maxime cum heredibus et liberorum propaginevolente deo careamus, ad honorem dei omnipotentis et beratissime virginis Marie, eius gloriose genitricis, omniumque sanctorum Cysterciensis ordinis abbaciam in propria hereditate nostra Bysowicz fundavimus serenissimi domini nostri Psremizel qui et Ottakarus, domini regni Boemi, ${ }^{c}$ ducis Austrie ac Styrie marchionisque Morauie, voluntate ac favoris liberalitate accedente necnon et reverendo in Christo patre ac domino, domino Brunone, episcopo Olomucensi, ${ }^{d}$ consenciente, in cuius dyocesi est fundata, nomen eidem abbacie Zmilenheim nostro ex nomine imponentes, venerabili domino Nicolao, Welegradensis ecclesie abbati, secundum Cysterciensis ordinis instituta, utpote a conventu Welegradensium propagatam commitendo, visitacionis officia seu alia quelibet iura ordinis predicti ab eodem suisque successoribus regulariter substituendis more debito percepturam.

3 Miroslav Plaček (Plaček-Futák 2006, 98, 362) je k tomuto údaji, pocházejícímu z Mars Moravicus Tomáše Pešiny z Čechorodu, skeptický. Rovněž tak Tomáš Borovský $(2005,175)$, jenž předpokládá, že k poničení kláštera došlo začátkem 20. let a že vizovičtí mniši přečkali válečná léta v Brně v některém z klášterních domů; jejich návrat předpokládá někdy ve druhé polovině 30 . let. 
kloní k určitější domněnce nepochybného, žel však nedatovaného plenění a poničení kláštera někdy mezi lety 1421-1424 (Borovský 2005, 175), ještě 30. prosince 1442 je však zmiňován opat Martin, převor Matyáš a klíčník Prokop (Peřinka 1906, 83).

V období po výše uvedeném roce je však asi po tř̌i desetiletí doložen zoufalý hospodářský stav kláštera (Borovský 2005, 177). K dalšímu plenění konventu došlo v roce 1466 přičiněním Bilíka z Kornic, jenž vtrhl na Moravu z povážského hradu Lednice (Plaček-Futák 2006, 98). Jako období poslední fáze zanikání Smilheimu jsou označována 60. léta 15. století, kdy se Vizovice stávaly předmětem zápisů a majetkových manipulací a vyvstala potřeba přesného vymezení zastavovaného klášterního majetku (Borovský 2012, 123); v roce 1481 je poslední zmínka o existenci konventu, jenž dospěl k svému konci, resp. jeho zbytek splynul s klášterem velehradským (Borovský 2005, 179). Údajná stavební oprava kláštera v roce 1495, zmiňovaná výše (LíbalPojsl 1994, 113), je tedy spojená s otazníkem; pokud k nějaké stavební činnosti došlo, muselo nejspíše jít již o opravy (nejspíše interiérové úpravy) v rámci sekularizovaného areálu.

\section{Kamenné architektonické články}

Pro dochované a dokumentované kamenné architektonické články je charakteristická poměrně nízká vypovídací hodnota, většina je torzální až amorfní a bez znaků, jež by dovolily komparaci a zařazení do kontextu. Zde proto uvádíme pouze výsek, přičemž veškeré dokumentované kamenné články ztotožňujeme s etapou fundace kláštera, tedy se 13. stoletím.

\section{Torzo hlavice (př́pory?) - obr. 3}

Blok s hlavicí je možno popsat jako torzo ukončení podpůrného článku, patrně jednoduché přípory, s vegetabilním dekorem; jde o kalichovou hlavici, u níž musíme předpokládat souvislé pokrytí v podobě schematického, suchého listoví, bez překrývání listů či náznaku pohybu, připomínající svým eliptickým tvarem a traktací listy buku. Analogicky s popisem Václava Mencla (v případě hlavice hradu Bezdězu s tvarově blízkým dekorem bukového listoví v kapli sv. Michala archanděla; Mencl 1960, 11, obr. 85) můžeme tvrdit, že jde o dekor, jenž „se již ploše př́imyká k základnimu kalichu, je (...) symetricky ztrnulý a vztyčuje se vertikálně“; toto pojetí připisuje Mencl období kolem roku 1275 (obr. 6:A).

Blok s drápkem - obr. 4:A, B, C

V př́ípadě bloku nalezeného v suti v rámci archeologického výzkumu v letech 2013-2014 jde o patku blíže neurčeného ostění. Oproti známým typům má však tento drápek jinou povahu; nepředstavuje ukončující prvek profilace ostění, většinou oblounové, ale je samostatným prvkem. Navíc je žlábkovitý útvar drápku od zcela rovného okosení ostění oddělen mírně vydutým půlkruhovým oblounem.

Blok kř̌žžní žeber - obr. 4:D, E

Blok spojující čtveřici žeber mírně vyžlabeného klínového profilu naznačuje úhlem jejich sbíhání, že byl určen pro obdélné pole. Na rubové straně má pravoúhlý otvor pro osazení kotvicí armatury, na lícové straně je uprostřed bloku menší, opět pravoúhlý otvor, jenž patrně sloužil k upevnění svorníkové desky.

Klenební žebro - obr. 4:F

Úsek klenebního žebra mírně vyžlabeného klínového profilu s hladkou plochou pro osazení a pravoúhlým otvorem pro spojovací armaturu v jednom z čel, na opačné straně je v ploše vysekaná kamenická značka ve tvaru majuskulového A. Písmeno je tvořeno dvěma př́ičkami a dvěma nespojitými šikmými tahy; horní příčka má výrazné přesahy a spodní je lomená směrem dolů (srovnej obr. 6:C). 

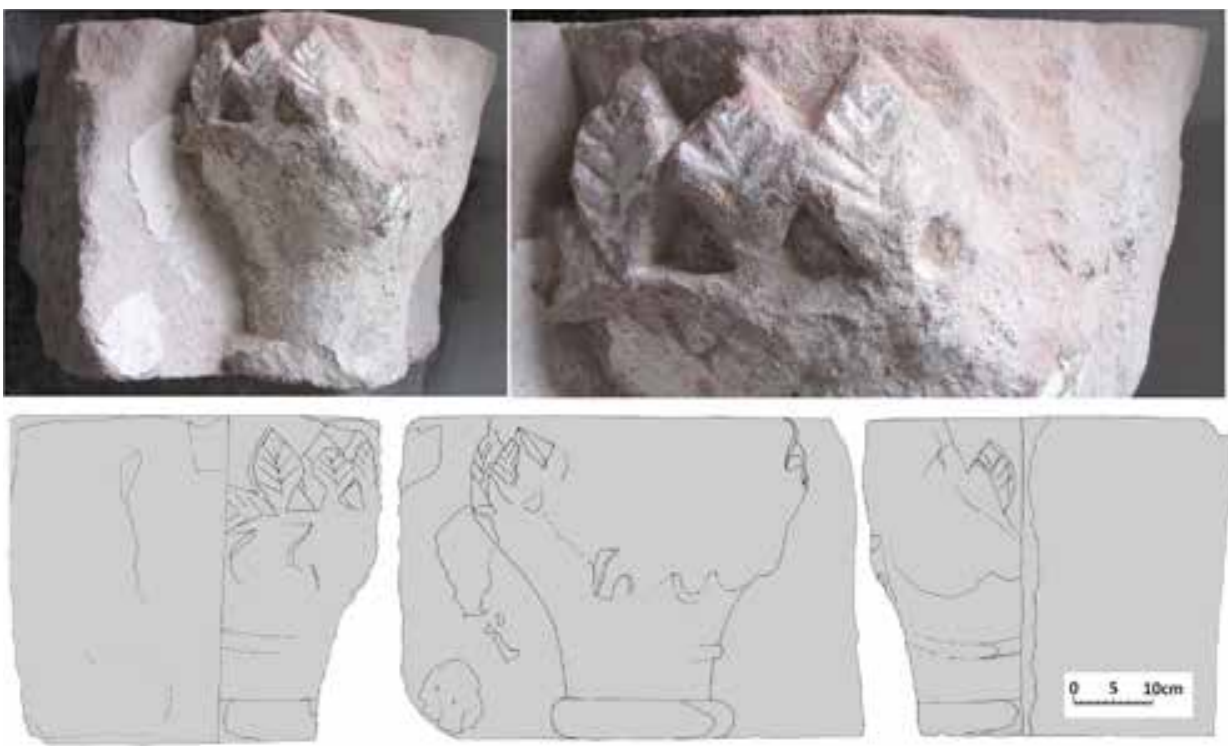

Obr. 3. Vizovice. Dokumentace torza hlavice s vegetabilním dekorem; nahoře - fotodokumentace dekoru na levé části, dole zaměření; zleva: pohled na levou stranu, čelní pohled a pravá strana. Foto a kresby R. Vrla, 2019.

Abb. 3. Vizovice. Dokumentation eines Kapitelltorsos mit vegetabilem Dekor; oben - Fotodokumentation des Dekors am linken Teil, unten - Vermessung; von links: Blick auf die linke Seite, Frontansicht und rechte Seite. Foto und Zeichnungen R. Vrla, 2019.

Fragment bloku př́pory (?) - obr. 5:A, B

Zachovaná je pouze symetrická středová profilace, boční zanikly. Předpoklad prvku jako součásti př́ípory či pasu je hypotézou, rovněž tvar - který lze popsat jako výžlabkem a drobným oblounkem odsazenou oblou homoli - je neobvyklý, bez nám známých analogií.

\section{Blok trnože (?) - obr. 5:C, D, E}

Teoreticky může jít o část (polovinu) báze přípory, větší část ložné plochy, jež by mohla nést informaci o navazujícím bloku (propojení bylo trnem, pro nějž byl v bloku vyhlouben pravoúhlý otvor), však zanikla. Předpokládaný celek byl patrně pětistranný, ukončený laloškou oddělenou od plochy lištou.

Soubor publikovaných kamenických značek (Kohoutek-Vácha-Vrla 2002, 431) bylo možné rozšíritit o nové (obr. 6:C).

\section{Kontext}

Pro komparaci s vizovickým tvaroslovím (Torzo hlavice [přípory?] - obr. 3) se zde přímo nabízí již zmiňovaná hlavice na královském hradě Bezdězu (obr. 6:A), jež souvisí v této fázi s rozsáhlým kolonizačním úsilím českého krále Přemysla Otakara II., které probíhalo i na východní Moravě; výstavba Bezdězu je kladena asi od druhé poloviny 60 . let do konce 70 . let 13. věku. ${ }^{4}$

Dalším prvkem propojujícím královské založení hradu Bezděz (a též cisterciácký klášter ve Žd'áře, fundaci Smilova bratra Bočka z Jaroslavic a Zbraslavi) s východní Moravou (byt' nikoli př́ímo s Vizovicemi) je detail talírových patek s hlubokým výžlabkem (,zdvojený talíř゙),

4 Otázka ukončení výstavby hradu Bezděz je stále otevřená, uvažuje se o 70. i 80. letech 13. století (viz Kuthan 1994, 63); viz dále. 

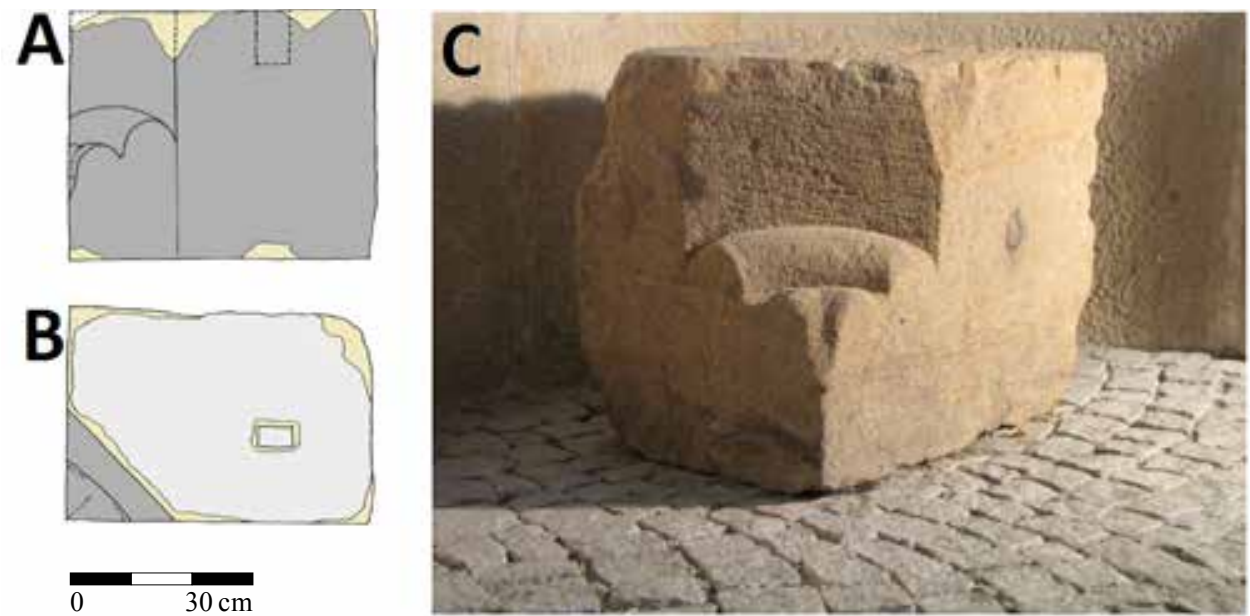

D
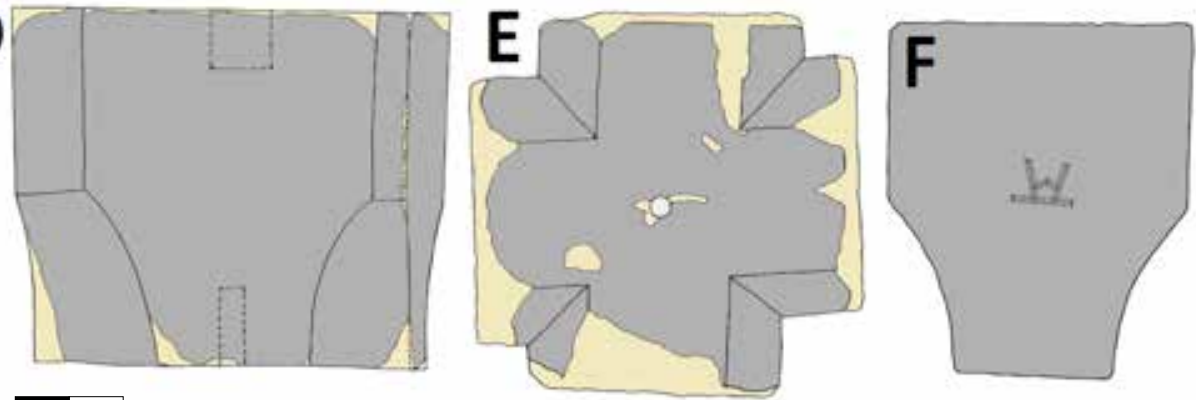

$0 \quad 10 \mathrm{~cm}$

Obr. 4. Vizovice. Výběr architektonických detailů. Nahoře - blok s drápkem: A - čelní pohled, B - pohled shora, C - fotodokumentace; dole vlevo - blok křížení žeber: $\mathrm{D}$ - boční pohled s profilem žebra a vyznačením otvorů, $\mathrm{E}$ - pohled na líc bloku; dole vpravo - klenební žebro: F - styčná hrana prvku s kamenickou značkou. Foto a kresby R. Vrla, 2019.

Abb. 4. Vizovice. Auswahl architektonischer Details. Oben - Steinblock mit Eckblatt: A - Frontansicht, B - Blick von oben, C - Fotodokumentation; unten links - Steinblock sich überschneidender Rippen: D - Seitenansicht mit Rippenprofil und Kennzeichnung der Löcher, E - Blick auf die Steinblockoberseite; unten rechts - Gewölberippe: F - Kontaktkante eines Elementes mit Steinmetzzeichen. Foto und Zeichnungen R. Vrla, 2019.

jež byly použity na Bezdězu v jižním paláci dolního hradu v letech ca 1265-1278 (Kovář 2017, 72) i na Buchlově ve fázi hradní kaple. Ve Žd’áře je tento detail př́itomen na západním portále, datovaném Z. Chudárkem (2001, 192, 194) mezi roky 1253-1255 (Kovář 2017, 72). Motiv drápku přimykajícího se k rovné ploše (Blok $s$ drápkem - obr. 4:A, B, C) nacházíme na okosení záklenku slepé arkády pod královskou tribunou kaple sv. Michaela archanděla hradu Bezděz (obr. 6:B); výstavba kaple je považována za poslední stavební fázi hradu a je řazena D. Líbalem, na rozdíl od V. Mencla $(1960,11)$ a kupř́íkladu také autorského kolektivu K. Benešovská, H. Ječný, D. Stehlíková a M. Tryml (1986, 408 pozn. 94), až do 80. let 13. století; D. Líbal potom nalézá blízká řešení v prostředí Hesenska $(2001,21)$. Předpoklad, že poklasická gotika, z níž vycházela bezdězská hut', prošla na cestě z Francie Hesenskem a Švábskem, formuluje již D. Menclová, ta však rovněž předpokládá ukončení prací v roce 1278 (1972, 241). Dalším prvkem, jenž spojuje Bezděz s Buchlovem, jsou jehlancovité, vějířovitě členěné konzoly (Kuthan 1994, 84); tyto se vyskytují na tribuně hradní kaple Bezdězu a na Buchlově v arkádovém ochozu kaple paláce (Štětina-Vácha-Vrla 2018, 36). Blízkou podobu řešení prvků obou královských hradních staveb 

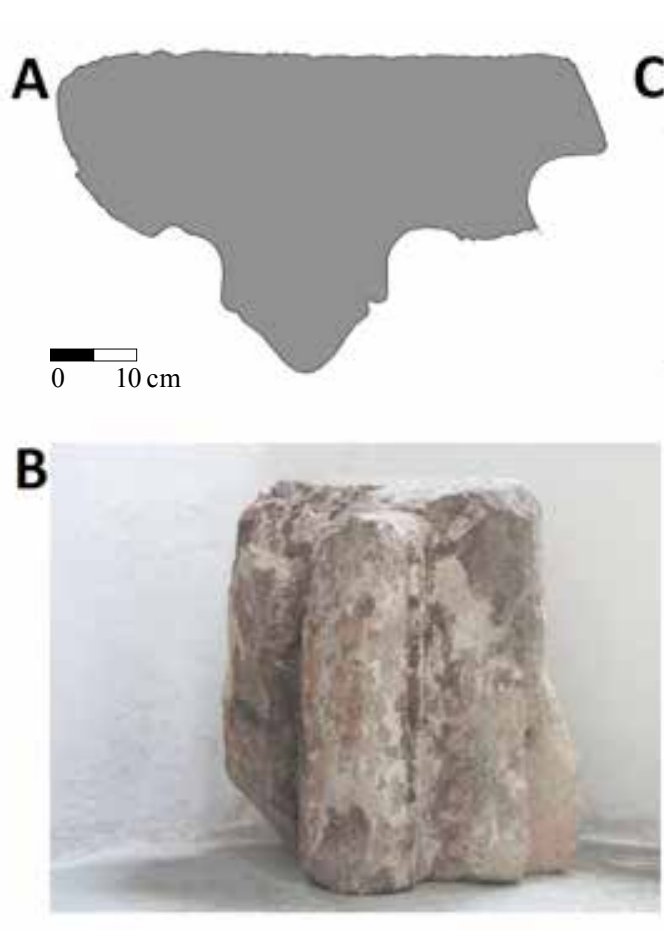
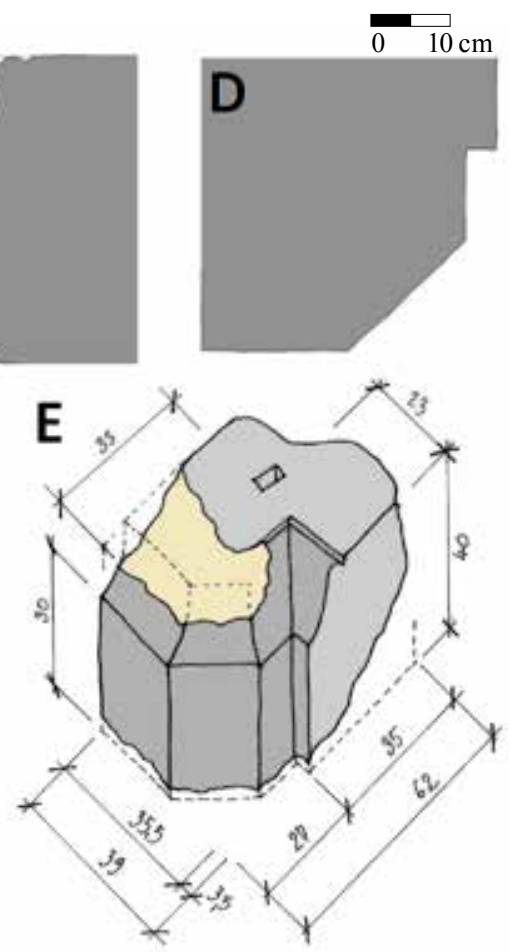

Obr. 5. Vizovice. Výběr architektonických detailů. Vlevo - fragment bloku př́pory: A - profilace, B - foto čelní plochy; vpravo - blok trnože: C - svislý řez prvkem, D - spodní plocha prvku, E - nákres prvku se základními rozměry. Foto a kresby R. Vrla, 2019.

Abb. 5. Vizovice. Auswahl architektonischer Details. Links - Steinblockfragement eines Dienstes: A - Profilierung, B - Foto der Vorderseite; rechts - Stegleistenblock: C - senkrechter Schnitt durch das Element, D - untere Fläche des Elements, E Aufriss des Elements mit Grundmaßen. Foto und Zeichnungen R. Vrla, 2019.

lze vidět i ve ztvárnění jednoduchých i zdvojených hrotitých oken paláců (Štětina-Vácha-Vrla 2018, 36).

Na základě výše uvedených skutečností je tedy možné předpokládat, že stavební hut' vizovické fundace mohla čerpat z okruhu řemeslníků královských hradních podniků, kteří se posléze pohybovali též na východní Moravě (Buchlov) a tvořili v přechodném románsko-gotickém pojetí.

Geograficky relativně vzdálené lokality Vizovic a Bezdězu byly propojeny personálně, prostřednictvím fundátora a panovníka. Smil ze Zbraslavi a Střílek byl souputníkem a družiníkem Přemysla Otakara II., čímž získal majetek v téměř neosídlených končinách na hranici (Plaček-Procházka 1986, 165); roku 1251 byl purkrabím na znojemském hradě, roku 1255 kastelánem přerovským a purkrabím na hradě Brumov, tedy již na východním pomezí Moravy. Ve stejné době, jak již bylo řečeno, zde královská hut' budovala hrad Buchlov, a to mohlo ovlivnit i stylové zabarvení řádové huti vizovického kláštera.

Bratr Smila Boček, patřící rovněž do nejbližšího okruhu dvořanů Přemysla, byl současně zakladatelem žd’árského cisterciáckého kláštera Fons Beatae Mariae Virginis (zal. 1252); zveřejnění listiny markraběte Přemysla (pozdějšího krále Přemysla Otakara II.), potvrzující dar novému klášteru ve hvozdech Vysočiny, byl př́itomen i Smil (Borovský 2011, 15). I proto nejen $\mathrm{z}$ důvodů úzké svázanosti cisterciáckých stavebních podniků prostřrednictvím řádových struktur - lze - v prrípadě těchto stavebních hutí - předpokládat propojení. Je sice zdůrazňována 

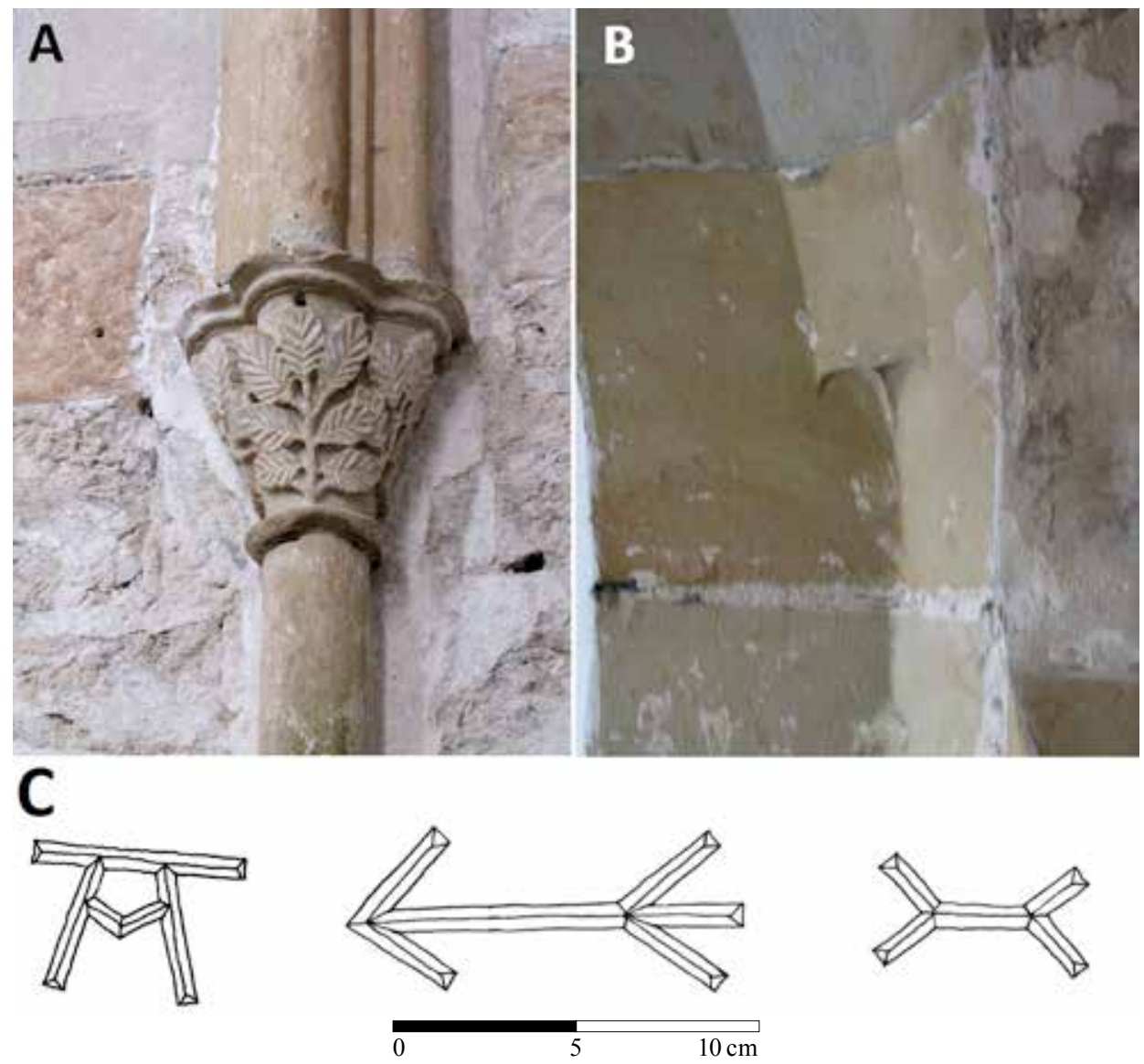

Obr. 6. Bezděz - vybrané architektonické detaily hradní kaple: A - hlavice s vegetabilním dekorem, B - blok s drápkem, C - Vizovice - nově zjištěné kamenické značky na středověkých architektonických detailech. Foto a kresby R. Vrla, 2019. Abb. 6. Bösig - ausgewählte architektonische Details der Burgkapelle: A - Kapitell mit vegetabilem Dekor, B - Steinblock mit Eckblatt, C - Vizovice - an mittelalterlichen architektonischen Details neu entdeckte Steinmetzzeichen. Foto und Zeichnungen R. Vrla, 2019.

skutečnost, že matkou Žd’áru byl Pomuk, zatímco do Vizovic př̌šli mniši z blízkého Velehradu (Borovský 2011, 14), fundace markraběte Vladislava Jindřicha, v daném kontextu to však nehraje zásadní roli.

Na rozdíl od Žd’áru, kde jsou mimo jiné zachované profily bohatě členěných ostění portálů, vizovické články často postrádají ukončující profilaci, zachovaly se zde sporadicky pouze oblouny a v jednom př́ípadě asymetrický hruškovec (Kohoutek-Vácha-Vrla 2002, 429, obr. č. 5); vizovické klenby byly tvořeny žebry s profilem tupého, mírně vyžlabeného klínu.

Co se kamenické značky v podobě písmene A týče, blízké podoby nacházíme kupříkladu na Velehradě či v klášteře Hradiště, přímou spojitost zde však nepředpokládáme.

\section{Archeologie}

Archeologické poznávání objektu zaniklého vizovického kláštera je relativně mladého data. Za akce spíše menšího rozsahu lze označit záchranné archeologické výzkumy provedené 


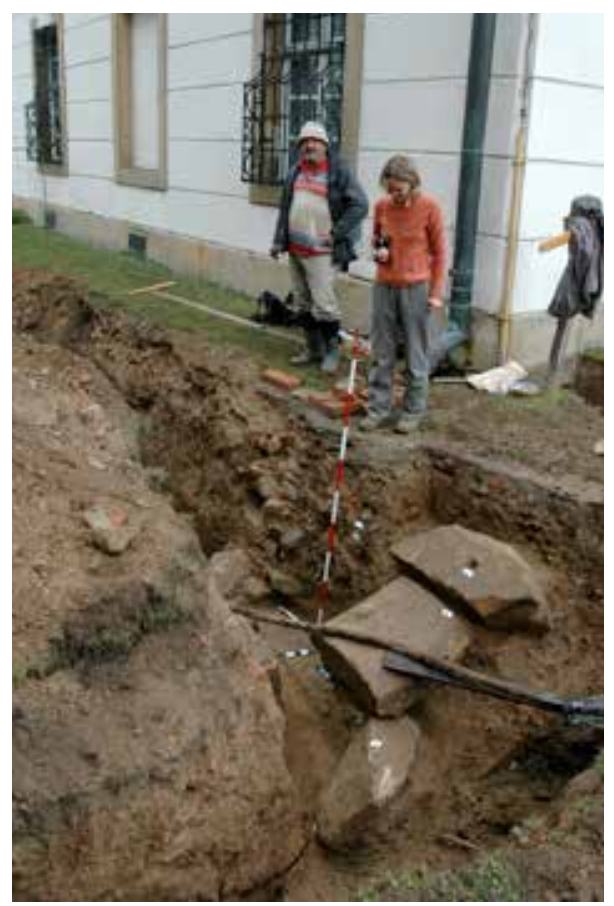

Obr. 7. Vizovice. Celkový pohled na pískovcové články zachycené v sondě S11 u jihovýchodního nároží jižního křídla zámku během archeologického výzkumu v roce 2008. Foto Z. Schenk, 2008.

Abb. 7. Vizovice. Gesamtansicht auf die in Sondierschnitt S11 an der Südostecke des Schlosssüdflügels während der archäologischen Grabung von 2008 entdeckten Sandsteinglieder. Foto Z. Schenk, 2008.

O stratigrafických pom̌rech na lokaliť vypovidá dokumentace jednotlivých vrstev, které postupně narůstaly nad intaktním geologickým podložím tvořeným jílem žlutohnědého zabarvení. Zachycené situace, zejména při severním, západním a východním křídle zámku, dokládají výrazné terénní úpravy raně novověkého stáŕí, jež patrně souvisely se snahou zarovnat přirozený terén svažující se k břehům Lutoninky (Kováčik-Plaštiaková 2009, 447-448; Schenk-Mikulík 2011, 5).

K důležitým zjištěním výzkumu toho roku patří zachycení několika kostrových hrobů, jež souvisejí s pohřbíváním v areálu kláštera. Výzkumem zachycené pohřby, dokládající existenci klášterního hřbitova, se nápadně koncentrovaly v sondě S6 situované podél východního průčelí jižního kř́ídla zámku. Z výsledků antropologického rozboru provedeného J. Kalou vyplývá, že vyzvednuté kosterní pozůstatky náležely nejen mužům, ale též ženám i dětem. U několika jedinců byly zjištěny patologické jevy. Ty vykazovaly např́íklad kosterní pozůstatky muže (hrob H2), jenž zemřel po padesátém roku života. Muž měl být robustní tělesné konstituce s dobře vyvinutou muskulaturou. $Z$ analýzy dále vyplývá, že v průběhu života utrpěl zlomeninu klíční kosti, mnohočetné zlomeniny žeber a též pravé stehenní kosti. Tato zjištěná zranění přežil. Trvalé následky mu přinesla špatně zhojená fraktura femuru vedoucí k částečnému zkrácení dolní končetiny. V hrobě H4 byl uložen muž starší padesáti let, jenž přežil sečné zranění, což dokládá

5 Geofyzikální měření na zámku ve Vizovicích bylo realizováno georadarem Katedry geografie PřF UP Olomouc v rámci testovacího režimu přistroje a rozšíření poznatků o vlastní technologii. Cílem projektu byla detekce podpovrchových struktur, jež by mohly souviset s historickou stavební činností na lokalitě (Kuda 2007). 


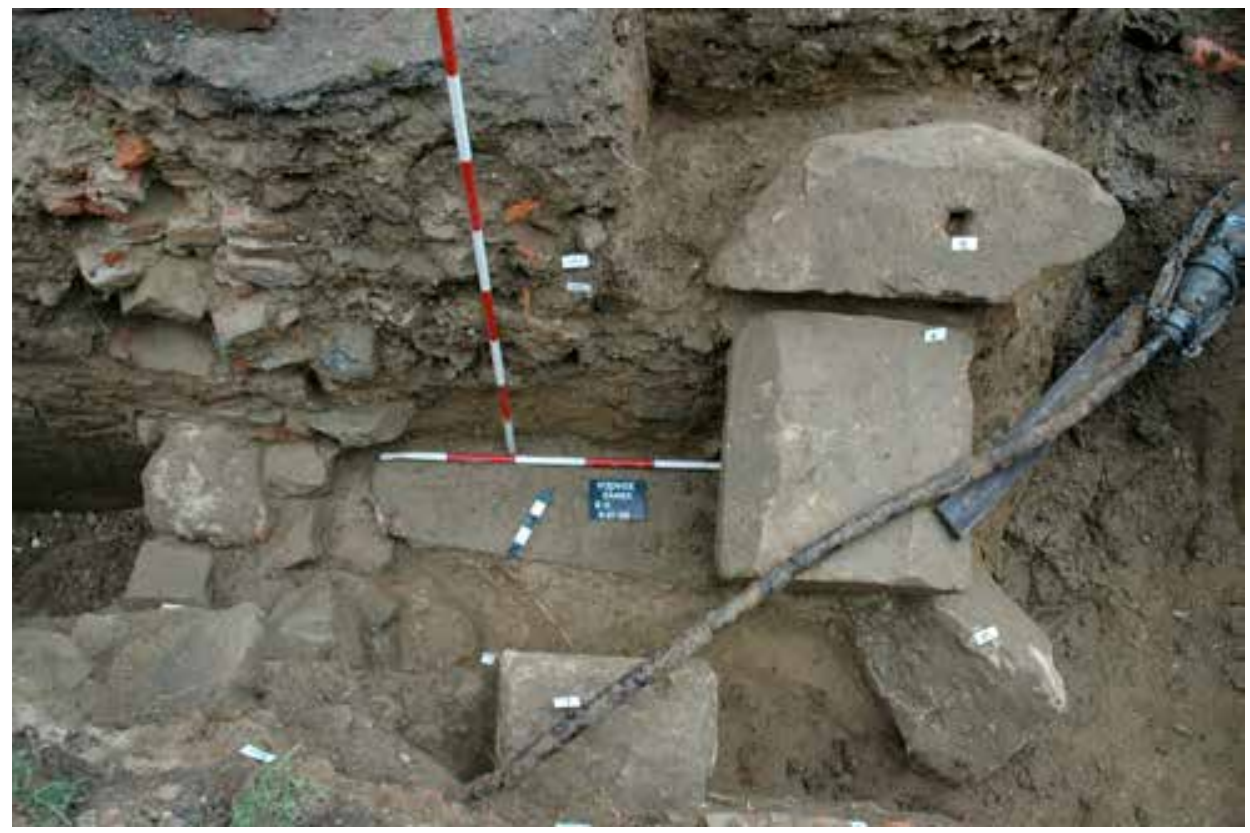

Obr. 8. Vizovice. Detailní pohled na koncentraci pískovcových článků zachycených v sondě S11 u jihovýchodního nároží jižního křídla zámku v roce 2008. Foto Z. Schenk, 2008.

Abb. 8. Vizovice. Detailansicht auf die in Sondierschnitt S11 an der Nordostecke des Schlosssüdflügels im Jahr 2008 entdeckte Sandsteingliederkonzentration. Foto Z. Schenk, 2008.

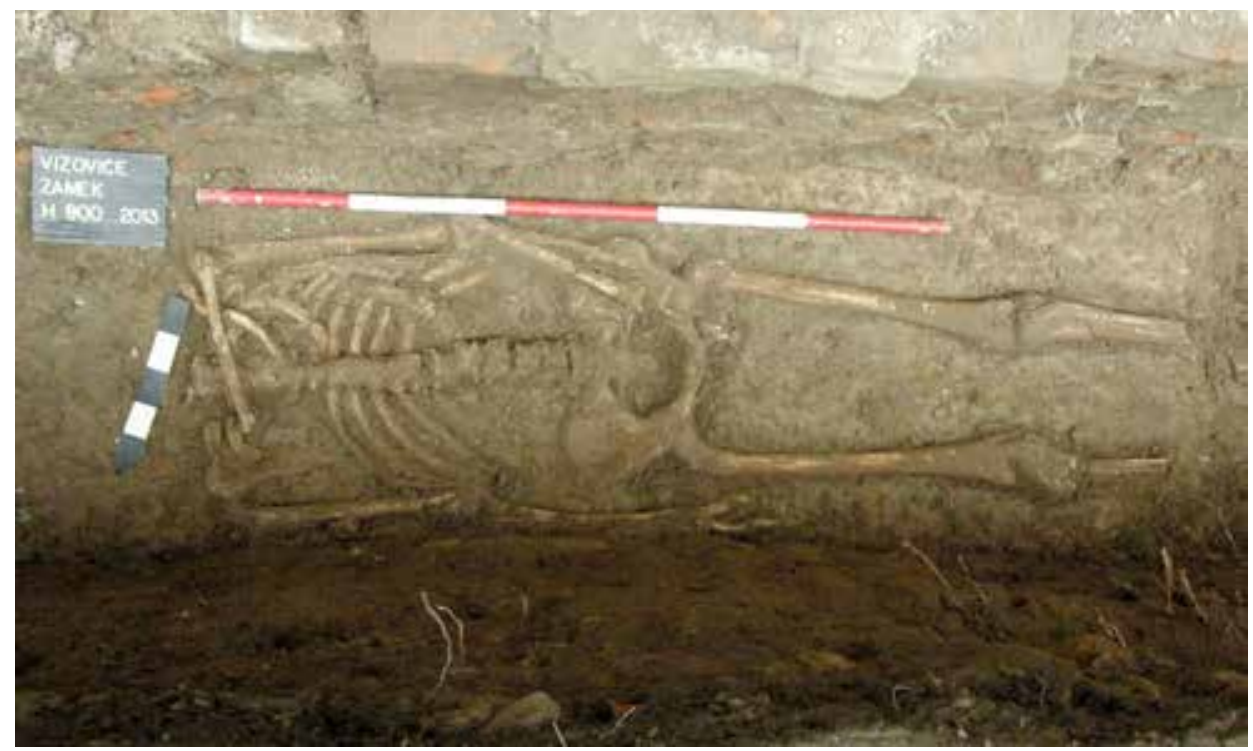

Obr. 9. Vizovice. Kostrový hrob zachycený v trase drenáže vedené podél základů jižní obvodové zdi jižního křídla zámku $v$ roce 2013 . Foto $Z$. Schenk, 2013.

Abb. 9. Vizovice. In der entlang den südlichen Außenmauerfundamenten des Schlosssüdflügels führenden Drainagentrasse im Jahr 2013 entdecktes Skelettgrab. Foto Z. Schenk, 2013. 


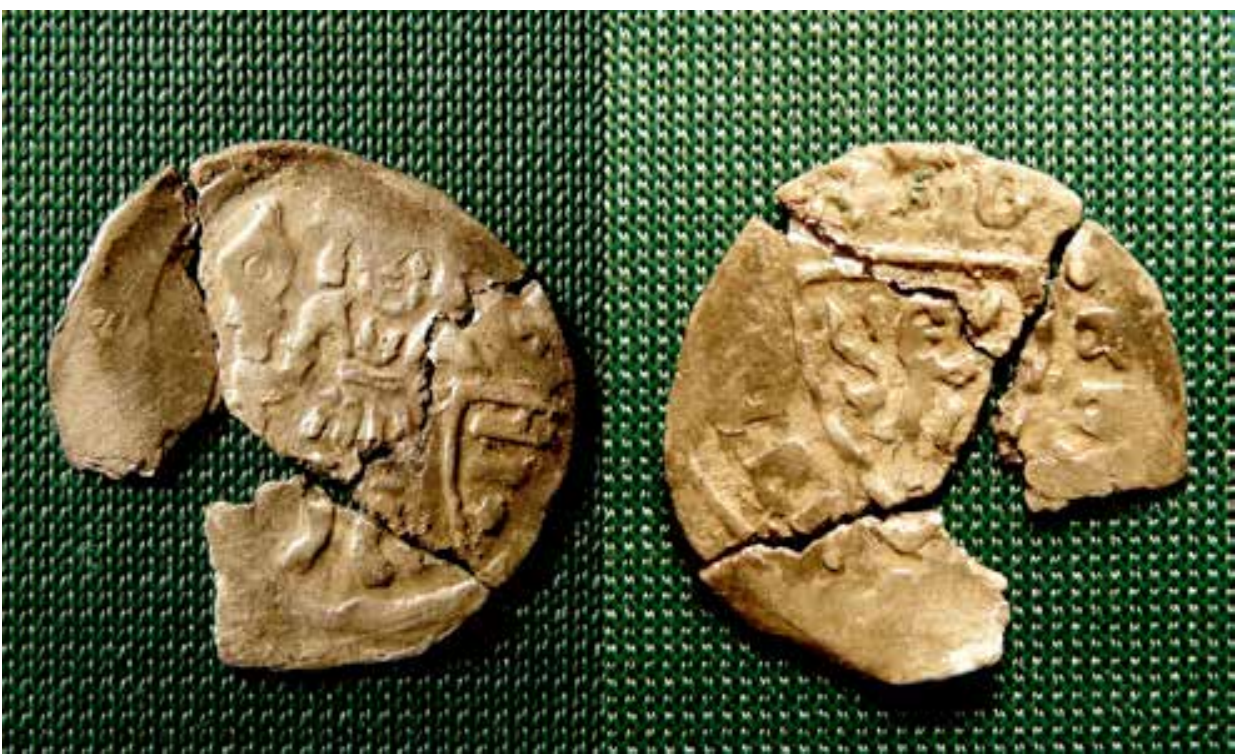

Obr. 10. Vizovice. Špatně dochovaný denár fenikového typu Přemysla Otakara II. Foto Z. Schenk, 2013. Abb. 10. Vizovice. Schlecht erhaltener pfennigartiger Denar von Přemysl Ottokar II. Foto Z. Schenk, 2013.

zhojená rána na temenní kosti lebky. V případě kostry dítěte (hrob H6) pohřbeného ve věku sedmi let byla zjištěna mírná porucha výživy, o čemž svědčí hypoplazie zubní skloviny (SchenkMikulík 2011, 6). ${ }^{6}$ V roce 2013 došlo během záchranného archeologického výzkumu, realizovaného v rámci akce „Zámek Vizovice - drenáž jižního křídla“, k zachycení dalšího kostrového hrobu (H1/2013) u základů jižní obvodové zdi jižního křídla zámku (obr. 9). Ze zásypu hrobové jámy pochází zlomek okraje hrnce zdobený obvodovým žlábkem a vlnicí, rámcově datovatelný do druhé poloviny 13. století. Důležitý nález představuje špatně dochovaná stř́ibrná mince, jež má mimořádný význam z datačního hlediska hrobové situace (Schenk-Mikulík 2014). Jde o drobný denár fenikového typu Přemysla Otakara II. (1253-1278). Vizovický exemplář se řadí do skupiny denárů typu Cach 971, které jsou datovány do 70. let 13. století. Na aversu mince je vyražen štít s českým lvem a opis se jménem a královským titulem panovníka $O T A-K A R V$ -SREX. Na reversu je zpříma stojící korunovaná postava držící v pravé ruce kopí a v levé štít (obr. 10). Tato skupina denárů je dosud známa především z rozsáhlejších či menších hromadných nálezů mincí z Bezuchova, Kyselovic, Moravského Krumlova a lokality Třebíč-Borovina (II) (Richtera-Zmrzlý-Videman-Grossmannová-Kučera 2011, 3, 7, kat. č. 2; Grossmannová 2015). Vizovický solitérní nález malého denáru fenikového typu Cach 971, vyzvednutý ze zásypu hrobu H1/2013, s velkou pravděpodobností datuje nejstarší horizont pohřbívání v okolí vizovického klášterního kostela.

Z movitých archeologických nálezů získaných v letech 2007-2013 lze vedle velkého množství zlomků kuchyňské keramiky středověkého a raně novověkého stáŕí zmínit soubor komorových kamnových kachlů. ${ }^{7}$ Největší koncentrace byla zaznamenána v úrovni požárových a destrukčních planýrek při severním okraji sondy S10, jež byla situována podél západního průčelí zámku. V kolekci pozdně gotických komorových reliéfně zdobených kachlů ze závěru 15. století lze uvést část kachle s motivem architektonické rozety s pravidelným vzorcem kružeb a lilií s vetknutou šesticípou hvězdou a dále zlomky kružby s liliemi tvořící původně vrcholovou

6 Kala 2009.

7 Detailní rozbor movitých archeologických nálezů bude předmětem samostatné studie. 


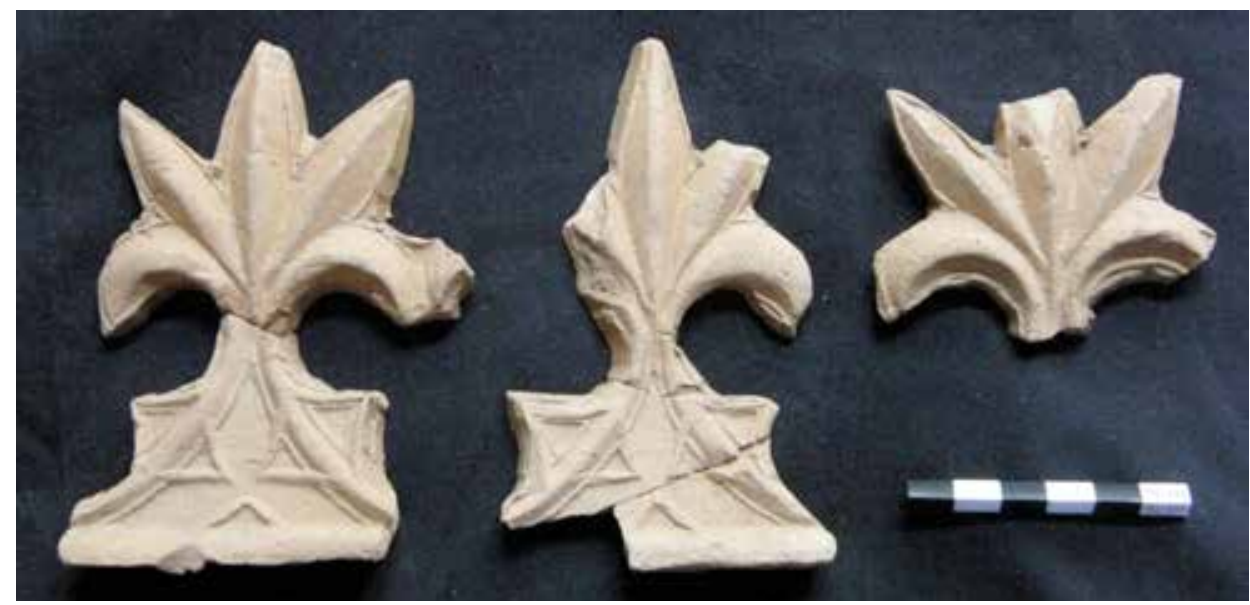

Obr. 11. Vizovice. Zlomky kružby s liliemi tvořící původně prořezávanou lištu. Foto Z. Schenk, 2008.

Abb. 11. Vizovice. Maßwerkfragmente mit ursprünglich eine Zahnleiste bildenden Lilien. Foto Z. Schenk, 2008.

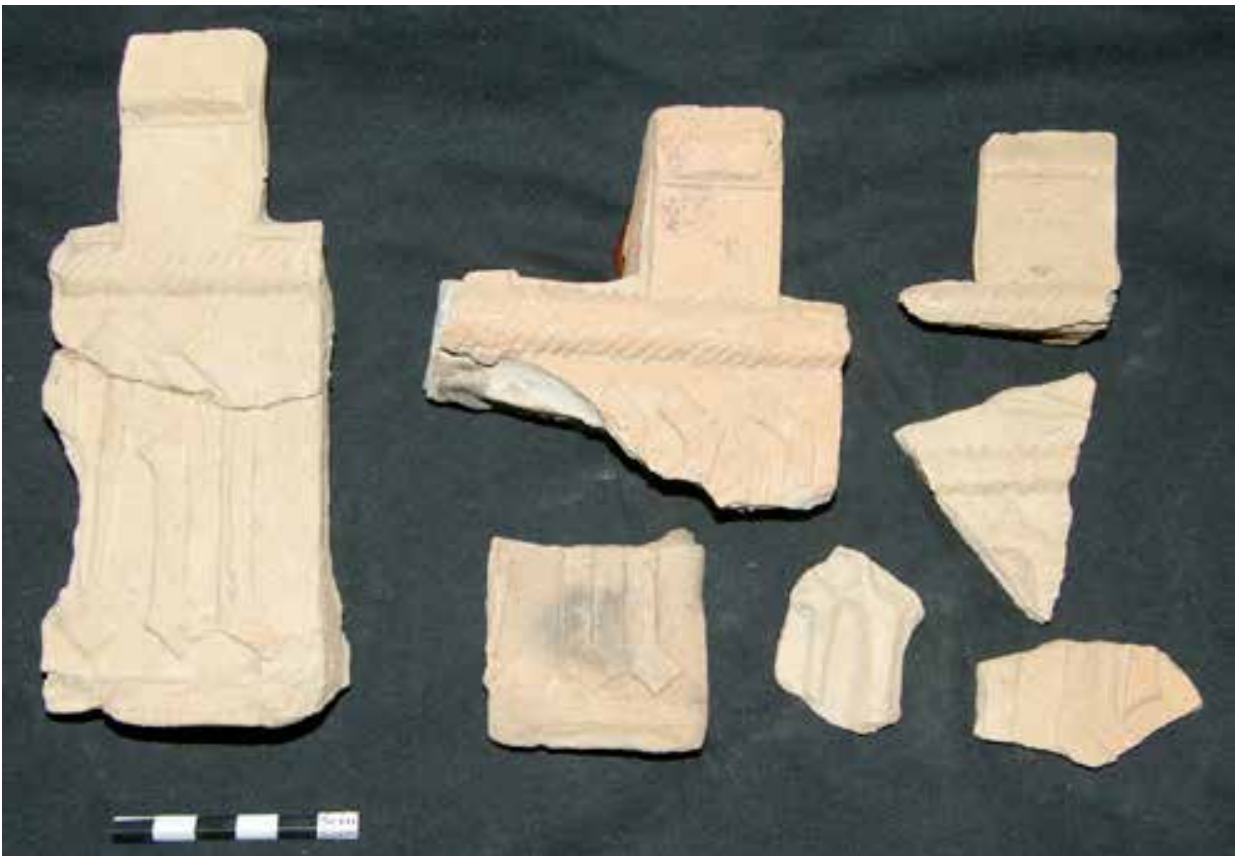

Obr. 12. Vizovice. Zlomky římsových kachlů s částí nápisu Maria. Foto Z. Schenk, 2013.

Abb. 12. Vizovice. Gesimskachelfragmente mit Teilen der Inschrift Maria. Foto Z. Schenk, 2013.

prořezávanou lištu (obr. 11). V kolekci je rovněž zastoupeno několik fragmentů římsových komorových kachlů s cimbuřím, provazcem a pod ním na čelní vyhřívací stěně umístěným nápisem Maria v gotické minuskule (obr. 12). Opakovaně se vyskytl heraldický motiv zobrazující korunovaného dvouocasého lva ve skoku s vysunutými drápy, vyceněnými zuby a vyplazeným jazykem. Lev je umístěn ve štítu, nad nímž je posazena velká koruna, a po jeho stranách stojí postavy štítonošů. Štítonoši jsou oděni do plášt’o̊, přiléhavých kabátců s náznakem spodní 


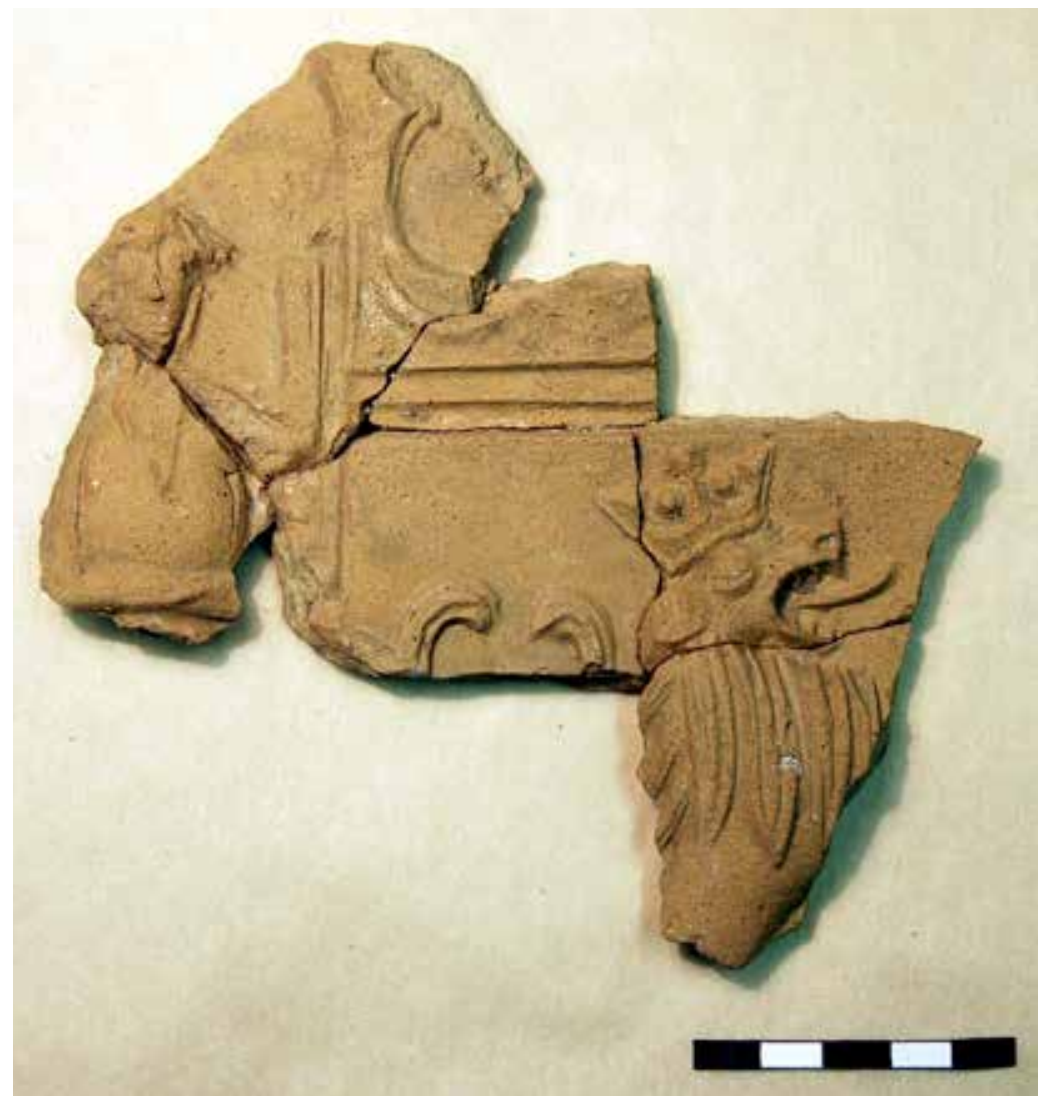

Obr. 13. Vizovice. Torzo kachle s motivem lva na štítě a štítonošů. Foto P. Halbsgutová, 2008.

Abb. 13. Vizovice. Torso einer Kachel mit dem Motiv eines Löwen auf einem Schild und Schildträgern. Foto P. Halbsgutová, 2008.

košile ve výstřihu. V úrovni bederní oblasti je znázorněn ozdobný pás (obr. 13-14). Z oblasti jihovýchodní Moravy pocházejí zcela analogické exempláře tohoto motivu z Otakarovy ulice v Uherském Hradišti, jež jsou datovány na přelom 15. a 16. století (Menoušková 2011, 166, obr. 10-11; Schenk-Mikulík 2011, 7). Ve vizovickém souboru je dále zastoupeno torzo heraldického motivu s erbem Prusinovských z Víckova, k němuž známe analogie z hradu Cimburka (Vitanovský 2008, 106, kat. č. 322). Soubor pozdně gotických kachlů z Vizovic, rámcově datovatelný na přelom 15. a 16. století, dokládá dosud neznámé aktivity, které lze hypoteticky spojit s údajnou stavební opravou kláštera v roce 1495 (Líbal-Pojsl 1994, 113).

\section{Pozůstatky zdiv odhalených archeologickou sondáží}

V rámci liniových výkopů prováděných v blízkém okolí zámku byly učiněny četné nálezy amorfních i lícovaných zdiv pocházejících z doby před výstavbou dnešního zámku (obr. 15).

Před západním průčelím jižního křídla šlo o dvojici téměř rovnoběžných subtilních zdí, širokých asi 100 a $80 \mathrm{~cm}$, probíhajících ve směru východ-západ a propojených druhotně vloženou zdí příčnou, širokou zhruba $100 \mathrm{~cm}$. K této prríčné zdi je asi v polovině její délky přiložena další zed', tvořená kameny loženými na hliněnou maltu. 


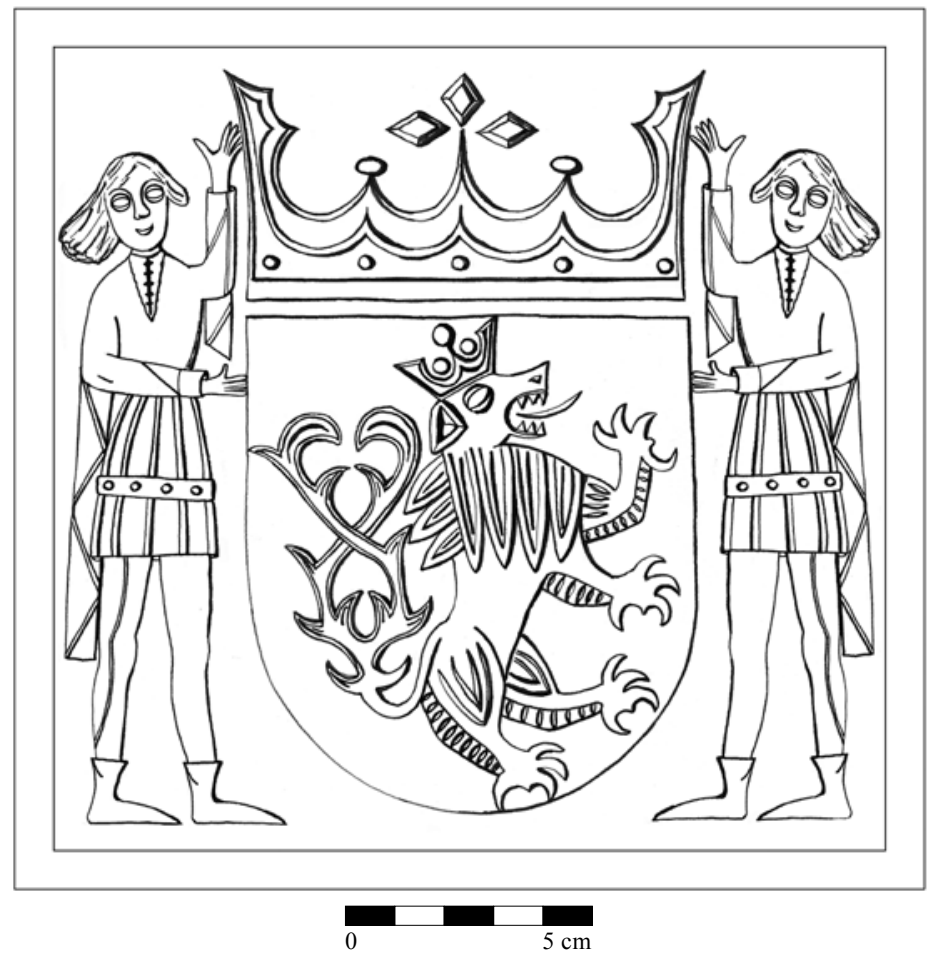

Obr. 14. Vizovice. Kresebná rekonstrukce reliéfu kachle s motivem lva na štítě a štítonošů. Kresba P. Halbsgutová, 2008.

Abb. 14. Vizovice. Zeichenrekonstruktion des Kachelreliefs mit dem Motiv eines Löwen und Schildträgern. Zeichnung P. Halbsgutová, 2008.

Při jižním boku jižního křídla byla ve východní partii odkryta další zdiva; západní z nich je téměř $165 \mathrm{~cm}$ široké a směřuje $\mathrm{k}$ jihu, další dvě, východně od něj, mají stejnou orientaci, ale jsou subtilnější (západní z nich je široké ca $100 \mathrm{~cm}$ ). Jižně odsud byla výzkumem zjištěna vnitřní hrana př́ikopu probíhajícího západovýchodním směrem.

Při jižní partii západního průčelí zámku byla obnažena trojice bloků amorfního kamenného zdiva na jižní straně a subtilní (ca $80 \mathrm{~cm}$ ), k západu směřující zed’ severně od ní.

Před severní částí západní fasády zámku byla zastižena asi $120 \mathrm{~cm}$ široká zed' probíhající západovýchodním směrem; $\mathrm{k}$ jejímu severnímu líci byla přiložena další zed' neznámé šířky.

Při severovýchodním nároží severního křídla zámku byl výkopy obnažen blok minimálně 180 cm širokého zdiva, situovaný zřejmě diagonálně k tomuto nároží. Další zdivo, s dochovaným severním lícem, bylo zachyceno před severním průčelím tohoto křídla.

Pozoruhodný objev byl zaznamenán před východním průčelím severního zámeckého křídla; byly zde odkryty dvě rovnoběžně probíhající zdi (široké ca $160 \mathrm{~cm}$ ), v jejichž protilehlých lících byly dochovány náběhy valené klenby, dokonce se zbytky interiérových omítek s ličkami. Na jižní straně ke zdivu přiléhala valounová dlažba. Její povrch se nachází zhruba $80 \mathrm{~cm}$ pod úrovní dnešního nádvoří, další pozůstatek téže dlažby byl obnažen v jeho severozápadním koutě.

Východně od zámku byl zachycen fragment zděné konstrukce sestávající ze dvou, dobou vzniku odlišných zdí; severní z nich by měla být starší, jižní má souviset s mostem přepažujícím př́kop situovaný východně.

Podle autorů archeologického výzkumu je možno o středověkém stáří uvažovat u široké zdi u jižního průčelí jižního kř́ídla či u východně ležících fragmentů, dále pak u zdiv při jižní partii 


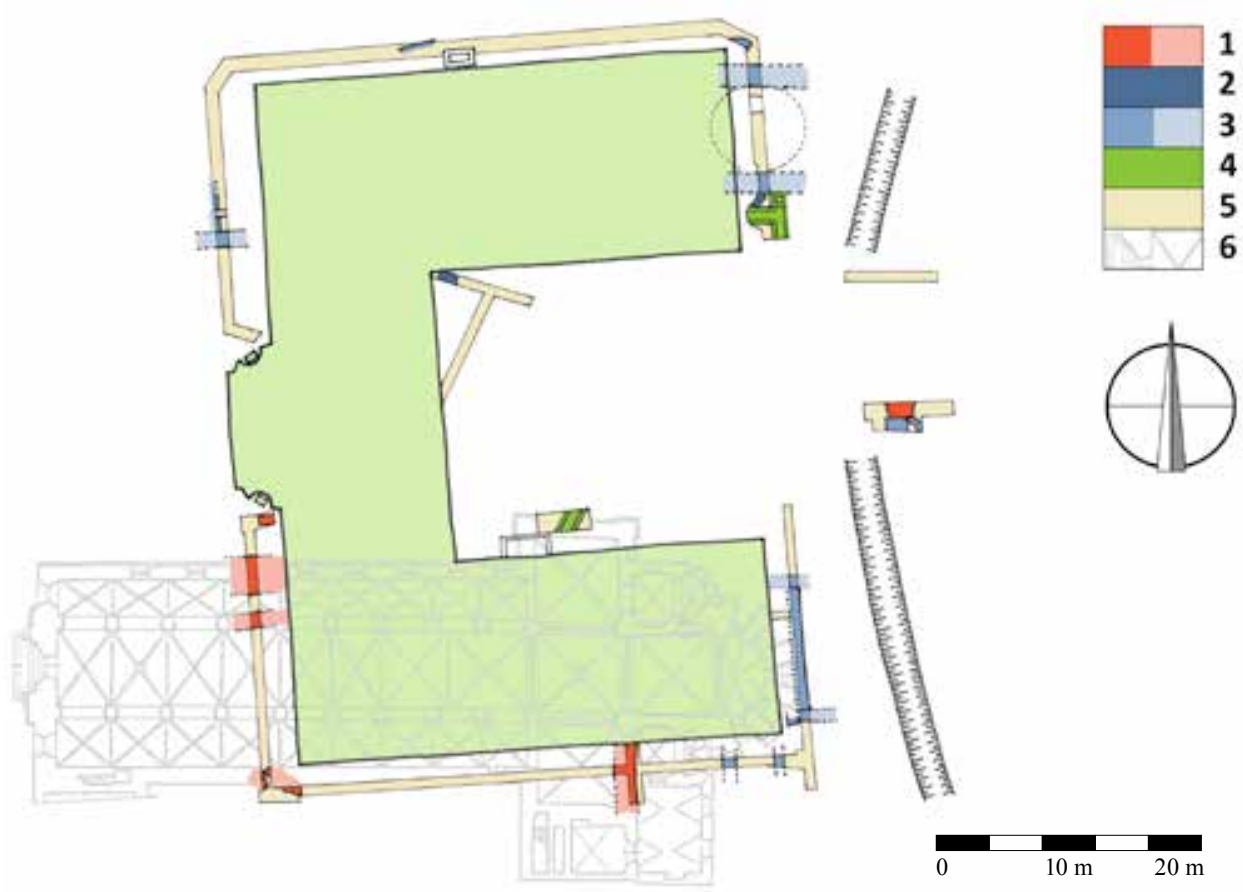

Obr. 15. Vizovice. Půdorysné schéma zámku a nejbližšího okolí s vyznačením zdiv nalezených v rámci archeologických výzkumů v letech 2007 a 2008. 1 - zdiva pocházející pravděpodobně ze středověkého období (světlý odstín - předpokládaný průběh zdiv v okolí sond); 2 - plochy předbarokní dlažby; 3 - předbarokní zdiva pocházející pravděpodobně z novověku (světlý odstín - předpokládaný rozsah zdiv v okolí sond); 4 - barokní zdiva související se stávajícím zámkem (odvodňovací kanály); 5 - plocha sond; 6 - půdorys baziliky bývalého cisterciáckého kláštera ve Žd’áru nad Sázavou. Kresba R. Vrla, 2019; půdorys žd’árské baziliky podle Kuthan 1983, 329, obr. XXI; úprava R. Vrla, 2019.

Abb. 15. Vizovice. Grundrissschema des Schlosses und der nächsten Umgebung mit Kennzeichnung der bei den archäologischen Grabungen der Jahre 2008 und 2009 entdeckten Mauerwerke. 1 - wahrscheinlich aus der Zeit des Mittelalters stammendes Mauerwerk (helle Schattierung - angenommener Verlauf der Mauerwerke in der Umgebung der Sondierschnitte); 2 - Flächen mit vorbarocker Pflasterung; 3 - wahrscheinlich aus der Neuzeit stammendes vorbarockes Mauerwerk (helle Schattierung - angenommener Umfang der Mauerwerke in der Umgebung der Sondierschnitte); 4 - mit dem bestehenden Schloss zusammenhängende barocke Mauerwerke (Entwässerungskanäle); 5 - Fläche der Sondierschnitte; 6 - Grundriss der Basilika des ehemaligen Zisterzienserklosters in Žd'ár nad Sázavou. Zeichnung R. Vrla, 2019; Grundriss der Basilika von Žd'ár nach Kuthan 1983, 329, Abb. XXI; Bearbeitung R. Vrla, 2019.

západního zámeckého průčelí. Další středověké zdivo má být situováno východně od zámku - je to severní partie odkryté skupiny zdiv.

\section{Pokus o interpretaci výsledků zkoumání při hledání stavební podoby kláštera Rosa Ma- riae a renesančního zámku Nový Smilheim}

Sporadicky odhalené fragmenty zdiv nám, žel, neposkytují jasnější obraz o podobě cisterciáckého kláštera Rosa Mariae. Jejich velká část je autory výzkumu spojována spíše s existencí opevněného renesančního zámku Nový Smilheim, který zde (jistě s použitím části stavebních konstrukcí kláštera) vznikl v 16. století.

Z historických pramenů vyplývá, že klášterní kostel, který existoval (respektive jeho část) ještě v 18. století, byl situován v místech dnešního jižního křídla zámku. ${ }^{8}$ Tento předpoklad

8 V roce 1749 při boření starého zámku vznikly v kapli velké trhliny, později - v roce 1766 - konzistoř odsouhlasila zboření této kaple (o stavbě samotné se dozvídáme pouze to, že měla špatnou šindelovou krytinu a cihelnou dlažbu), s tím, že na jejím místě bude vystavěna kaple nová (Čižmář 1933, 247, 248). 
potvrzuje poměrně velké množství stř̌edověkých architektonických detailů druhotně použitých v trnoži zdiva tohoto zámeckého křídla - jejich četnost je vyšší ve východní části. Kolem jižního křídla se též nachází největší množství zdiv hypoteticky řazených do středověku. Je velmi pravděpodobné, že klášterní kostel se nacházel v jeho místech. Zdivo při západní straně zámku (obr. 15) může nasvědčovat tomu, že kostel, u něhož musíme předpokládat typické trojlodní uspořádání, svým západním průčelím předstupoval před půdorysnou úroveň západní fasády dnešního zámku. Široká zed' vybíhající zpod jižního průčelí zámku může indikovat základ boční zdi jižní části transeptu. Vzhledem k půdorysnému průběhu zdi (ale i s přihlédnutím k orientaci traktu zachyceného před východním průčelím severního křídla) je pravděpodobné, že klášterní kostel byl orientovaný poměrně přesně k východu - na rozdíl od dnešní pravidelné zámecké dispozice, jejíž osa je mírně pootočena.

Rovněž je pravděpodobné, že rajský dvůr byl ve Vizovicích situován, podobně, jako např́iklad v Předklášteří (Porta coeli), při severní straně klášterního kostela. Stavba s klenutým interiérem vybíhající zpod severního křídla zámku (pocházející dle nálezové zprávy archeologického výzkumu až z období 16. století) by tak mohla obsahovat konstrukce středověkého klášterního objektu.

V souvislosti s existencí renesančního Nového Smilheimu je pozoruhodné zjištění existence př́ikopu, který zřejmě souvisí s opevněním zámku. Jeho pozůstatky byly zjištěny na jihovýchodní a východní straně dnešní zámecké stavby. Podobně lze nahlížet na předpokládanou bránu ve východní části renesančního zámku. Areál Nového Smilheimu můžeme tedy poměrně dobře vymezit na východní straně, kde je doložen př́íkop a při jeho západním okraji potom hradba (?) využívající i starší konstrukce. Patrně zde byla situována i brána do areálu - př́istup byl tedy veden $\mathrm{v}$ podstatě $\mathrm{v}$ dnešní trase propojující budovu předzámčí s vlastním zámkem. Renesanční zámek mohl využít existující klášterní budovy, svým rozsahem zřejmě přesahující jeho dnešní plochu. $\mathrm{K}$ jeho konstrukcím lze dále přičíst i zdivo objektu před východním průčelím jižního kř́ídla situovaného pravděpodobně za presbytářem původního klášterního kostela.

$\mathrm{V}$ rámci tohoto sídla existoval nadále i původní klášterní kostel, i když nevíme, v jakém rozsahu (viz pozn. 6). Je možné, že podobně jako např́íklad v Oslavanech byla jeho část využita profánně a pouze jeho východní partii byla ponechána úloha sakrálního prostoru (zámecké kaple). $\mathrm{Z}$ architektonické výbavy tohoto zámku jsou dodnes zachovány pouze dva bloky v kameni sekaného ostění fasádních otvorů.

K neméně pozoruhodným zjištěním patři skutečnost, že před stavbou barokního zámku došlo k výrazné planýrce terénu; na jižní straně byl terén snížen, na severní byl naopak dorovnán poměrně mohutnými násypy. Původní terén, na němž byl klášter budován, se tedy mírně svažoval od jihu k severu. Zámek, budovaný podle projektu F. A. Grimma, evidentně nepočítal s využitím žádných zdiv starších objektů a jeho stavbě předcházela téměř plošná demolice Nového Smilheimu s výraznou terénní úpravou, jež zde vytvořila poměrně rozměrnou, rovinnou plochu. Kompletní dostavba zámku narazila na nesouhlas arcidiecéze se zbořením staré kaple (viz pozn. 8), která se nacházela $\mathrm{v}$ místech dnešního jižního křídla zámku. S velkou pravděpodobností se můžeme domnívat, že se zde dochovala (byt' v upravené podobě) východní část původního klášterního kostela. Její zboření znamenalo zánik poslední nadzemní části tohoto jistě monumentálního objektu; na tomto místě je nutno upozornit na areál dnešního předzámčí, které obsahuje konstrukce pocházející z doby před výstavbou dnešního zámku (obr. 1:C).

Autorské části článku R. Vrly $(1,6,7)$ vznikly v rámci plnění výzkumného cíle Národního památkového ústavu „Výzkum nemovitých památek v ČR. Aplikace nových metodik průzkumu a dokumentace - ohrožené druhy památek a jejich vybrané exempláře“, financovaného z institucionální podpory Ministerstva kultury ČR na dlouhodobý koncepční rozvoj výzkumné organizace. 


\section{Prameny a literatura}

ARCHAIA Olomouc, o.p. s., Feat. NPÚ, ÚOP v Kroměříži, 2008: „Zámek Vizovice, rekonstrukce stávající kanalizace, nálezová zpráva o provedení zjištovacího záchranného archeologického výzkumu“, Olomouc, ulož. v archivu NPÚ, ÚOP v Kroměřiži.

ARCHAIA Olomouc, o. p. s., Feat. NPÚ, ÚOP v Kroměříži, 2009: „Zámek Vizovice, rekonstrukce stávající kanalizace, nálezová zpráva o provedení archeologického výzkumu“, Olomouc, ulož. v archivu NPÚ, ÚOP v Kroměříži.

BENEŠOVSKÁ, K.-JEČNÝ, H.-STEHLÍKOVÁ, D.-TRYML, M., 1986: Nové prameny k dějinám klášterního kostela cisterciáků na Zbraslavi, Umění XXXIV, 385-409.

BOROVSKÝ, T., 2005: Kláštery, panovník a zakladatelé na středověké Moravě. Brno.

- 2011: Listina Smila ze Stř́ílek a založení vizovického kláštera, Východní Morava 1, 11-26.

- 2012: Tržní privilegium pro Vizovice z roku 1466, Východní Morava 2, 121-127.

CDB V/1: Codex diplomaticus et epistolaris regni Bohemiae V/1 (Šebánek, J.-Dušková, S., edd.). Pragae 1974.

ČIŽMÁŘ, J., 1933: Dějiny a paměti města Vizovic. Brno.

GROSSMANNOVÁ, D., 2015: Poklad z Bezuchova jako významný pramen pro moravské peněžní dějiny 13. století, Studia Historica Brunensia 62, 115-133.

CHUDÁREK, Z., 2001: Fragment západního portálu klášterního kostela ve Žd’áru, ZPP 61, 188-194.

KALA, J., 2009: Antropologický posudek, rkp., ÚAPP Brno, v. v. i.

KOHOUTEK, J., 2002: Vizovice (okr. Zlín), PV 43 (2001), 299.

- 2006: Vizovice (okr. Zlín), PV 47, 286.

KOHOUTEK, J.-VÁCHA, Z.-VRLA, R., 2002: Nové poznatky o gotické architektuře jihovýchodní Moravy - Neue Erkenntnisse über die gotische Architektur im südöstlichen Mähren, AH 27, 425-444.

KOVÁČIK, P.-VESELÁ, P., 2008: Vizovice (k. ú. Vizovice, okr. Zlín), PV 49, 455.

KOVÁČIK, P.-PLAŠTIAKOVÁ, M., 2009: Vizovice (okr. Zlín), PV 50, 447-448.

KOVÁŘ, M., 2017: Klášter Studnice blahoslavené Panny Marie / Fons Beatae Mariae Virginis. Po stopách žd’árského mramoru. Hledání původu surovin použitých při stavbě gotického kláštera, 58-84. Praha.

KUDA, F., 2007: Technická zpráva geofyzikálního průzkumu Zámek Vizovice 2007, rkp., Katedra geografie PřF UP Olomouc.

LÍBAL, D., 2001: Katalog gotické architektury v České republice do husitských válek. Praha.

KUTHAN, J., 1994: Česká architektura v době posledních Přemyslovců. Vimperk.

- 1983: Počátky a rozmach gotické architektury v Čechách. K problematice cisterciácké stavební tvorby. Praha.

LÍBAL, D.-POJSL, M., 1994: Vizovice. Historie. In: Řád cisterciáků v českých zemích ve středověku (Houšková, D., ed.), 113. Praha.

MENCL, V., 1950: Románská a gotická hlavice jako prostředek k datování české architektury, ZPP 10, $1-24$.

MENOUŠKOVÁ, D., 2011: Městská heraldika na kachlích ze sbírky Slováckého muzea, Slovácko LII (2010), 161-173.

PEŘINKA, F. V., 1906: Klášter cisterciácký ve Vizovicích. Kapitola z moravské monasteriologie, Sborník historického kroužku VII, č. 1-2, 88-97.

PEŘINKA, V., 1907: Vizovský okres. Vlastivěda moravská. Hradišstský kraj. Brno.

PLAČEK, M.-PROCHÁZKA, R., 1986: K problematice opevněných sídel přelomu raného a vrcholného feudalismu na Moravě - Zur Problematik der befestigten Sitze an der Wende des Früh- und Hochfeudalismus in Mähren, AH 11, 159-170.

RICHTERA, L.-ZMRZLÝ, M.-VIDEMAN, J.-GROSSMANNOVÁ, D.-KUČERA, L., 2011: Moravské denáry fenikového typu Přemysla Otakara II. z nálezu Třebíč-Borovina (II) a jejich analýza, Folia Numismatica 25, 3-17.

SCHENK, Z.-MIKULÍK, J., 2011: Vizovice ve světle nových archeologických výzkumů, Valašsko 27, č. 2, $5-7$.

- 2014: Zámek Vizovice - drenáž jižního kř́́dla zámku. Nálezová zpráva o provedení archeologického výzkumu. ARO 004/2014. Archaia Olomouc, o.p.s.

ŠTĚTINA, J.-VÁCHA, Z.-VRLA, R., 2018: Kamenická výbava hradů. In: Hrady Zlínského kraje (Janiš, D.-Vrla, R., edd.), 36-44. Lukov.

ŠEBÁNEK, J., 1959-1961: Vizovická listina Smila ze Stř́lek z r. 1261 jako historický pramen především k otázce osídlení na Valašsku, Valašsko VIII, 29-39. 
VITANOVSKÝ, M., 2008: Heraldické motivy. In: Krása, která hřeje. Výběrový katalog gotických a renesančních kachlů Moravy a Slezska (Menoušková, D.-Měřínský, Z., edd.), 89-115. Uherské Hradiště.

VRLA, R., 2013-2014: Zámek Vizovice jižní kř́ídlo, dokumentace architektonických detailů, druhotně použitých ve zdivu. Operativní průzkum a dokumentace. Elaborát uložen v NPÚ, ÚOP v Kroměříži.

- 2019: Zámek Vizovice. Dokumentace architektonických detailů, volně ložených v areálu SZ Vizovice. Operativní průzkum a dokumentace. Elaborát uložen v NPÚ, ÚOP v Kroměřiži.

\section{Zusammenfassung}

\section{Der gegenwärtige Kenntnisstand über das Aussehen des Zisterzienserklosters in Vizovice}

Über die Überreste des fast vergessenen Zisterzienserklosters Rosa Mariae - Smilheim in Vizovice wurde auf den Seiten des vorliegenden Sammelbandes bereits im Jahr 2002 in knapper Form referiert, nach 2013 wurden im Rahmen relativ umfangreicher Sanierungsarbeiten in der direkten Umgebung des Schlosses weitere wertvolle Informationen gewonnen. Besonders dort wurde eine Reihe von bisher unbekannten architektonischen Details $(101+29$ Steinelemente) gehoben bzw. in den unteren Mauerwerkspartien des südlichen Schlossflügels entdeckt; von der Architektur selbst konnten ferner die Überreste älterer Mauerwerke dokumentiert werden, die außerhalb der Fläche des heutigen Schlossgebäudes erfasst wurden. Jedwede dokumentierte Steinglieder, die aus grobkörnigem Sandstein gefertigt wurden, identifizieren wir mit der Gründungsetappe des Klosters.

Zum Gründungsakt des Klosters durch den Brumover Kastellan Smil von Zbraslav und Stř́lek ist eine Urkunde als Fälschung aus dem 14. Jahrhundert erhalten geblieben. Nach nicht ganz einem halben Jahrhundert seiner Existenz wurde Smilheim im Jahr 1314 von Matthäus Czák geplündert, und nach einer Zeit des wirtschaftlichen Niedergangs - in den Jahren 13611368 verschlechterten sich die wirtschaftlichen Verhältnisse - ging das Kloster infolge der Hussitenkriege praktisch unter. Der heutige Stand der Erkenntnisse neigt zu der Annahme einer nicht angezweifelten, leider jedoch undatierten Plünderung und Zerstörung des Klosters irgendwann zwischen den Jahren 1421-1424, obgleich noch am 30. Dezember 1442 ein Abt, ein Prior und ein Burgvogt erwähnt werden. Für die Zeit nach dem oben aufgeführten Jahr ist jedoch ungefähr über drei Jahrzehnte hinweg ein hoffnungsloses wirtschaftlicher Zustand belegt. Als Zeitraum für die letzte Untergangsphase von Smilheim werden die sechziger Jahre des 15. Jahrhunderts bezeichnet, als das entstehende Vizovice zum Gegenstand von Verschreibungen und Eigentumsmanipulationen wird und die Notwendigkeit einer genauen Abgrenzung des verpfändeten Klosterbesitzes aufkam; aus dem Jahr 1481 stammt die letzte Erwähnung von der Existenz des Konvents, der an seinem Ende angelangt war, bzw. dessen Rest mit Kloster Velehrad zusammenfloss.

Smil von Zbraslav und Stř́lek war Weggefährte und Gefolgsmann von Přemysl Ottokar II., wodurch er in fast unbesiedelten Gegenden an der Grenze Besitz erwarb; im Jahr 1251 ist er Burggraf auf der Znaimer Burg, im Jahr 1255 Kastellan der Burg in Přerov und Burggraf auf Burg Brumov, also bereits an der Ostgrenze Mährens.

Für einen Vergleich mit der Formgebung der Steinglieder aus Vizovice bietet sich die Architektur der königlichen Gründung von Burg Bösig (Bezděz), die in dieser Phase mit den ausgedehnten Kolonisationsbemühungen des böhmischen Königs Přemysl Ottokar II. zusammenhängen, und der im Hinblick auf Vizovice nahegelegene, ebenfalls königliche Bau von Burg Buchlau (Buchlov) an. Eine indirekte Analogie sehen wir dann auch zum Zisterzienserkloster in Žd'ář, einer Gründung von Smils Bruder Boček von Jaroslavice und Zbraslav. Aufgrund der oben aufgeführten Tatsachen kann demnach angenommen werden, dass die Bauhütte der Vizovicer Gründung aus dem Umkreis der Handwerker der königlichen Burgunternehmungen schöpfen konnte, die sich schließlich auch in Ostmähren (Buchlau) bewegten und vor allem in einem romanisch-gotischen Übergangsstil bauten. 
Die sporadisch freigelegten Mauerwerksfragmente des Schlosses liefern uns - leider - kein deutlicheres Bild vom Aussehen des mittelalterlichen Klosters. Aus den historischen Quellen geht hervor, dass die Lage der Klosterkirche, die (bzw. deren Teil) noch im 18. Jahrhundert existierte, sich an den Stellen des heutigen Südflügels des Schlosses befand. Darauf deutet auch die während einer archäologischen Grabung von 2008 entdeckten Konzentration von Skelettgräbern in der Nähe der südöstlichen Ecke des Schlosssüdflügels hin. Der älteste Bestattungshorizont in der Umgebung der Vizovicer Klosterkirche wird durch ein im Jahr 2013 an den Fundamenten der südlichen Außenmauern des Südflügels freigelegtes Grab belegt, aus dessen Auffschüttung neben Keramik der chronologisch sensible Fund eines kleinen pfennigarten Denars (Cach 971) von Přemysl Ottokar II. stammt, der in die siebziger Jahre des 13. datiert wird. Das Mauerwerk an der Westseite des Schlosses kann darauf hindeuten, dass die Kirche, bei welcher wir eine typische dreischiffige Anlage annehmen müssen, mit ihrer Westfassade über das Grundrissniveau der Westfassade des heutigen Schlosses hinausragte. Die breite unter der Südfassade des Schlosses hervorspringende Mauer kann das Fundament der Seitenwand des südlichen Teiles eines Transeptes darstellen. Im Hinblick auf den Grundrissverlauf der Mauer (aber auch unter Berücksichtigung der Orientierung des vor der Ostfassade des Nordflügels erfassten Traktes) ist es wahrscheinlich, dass die Klosterkirche relativ genau nach Osten hin ausgerichtet war - im Unterschied zur heutigen regelmäßigen Schlossdisposition, deren Achse leicht ausschert.

Ebenso wahrscheinlich ist, dass sich die Lage des Paradieshofs, ähnlich wie beispielsweise in Předklášteří (Porta coeli), an der Nordseite der Klosterkirche befand. Der unter dem Nordflügel des Schlosses hervorragende (gemäß dem Fundbericht der archäologischen Grabung erst aus der Zeit des 16. Jahrhunderts stammende) Bau mit gewölbtem Innenraum könnte somit die Konstruktion eines mittelalterlichen Klosterobjektes enthalten.

Radim Vrlas Teilnahme als Coautor der vorliegenden Studie erfolgte im Rahmen der Erfüllung des Forschungszieles des Nationalen Denkmalinstituts: Die Erforschung unbeweglicher Denkmäler in Tschechien. Die Anwendung neuer Untersuchungsmethoden und Dokumentation - bedrohte Denkmalarten und ausgewählte Exemplare von ihnen. Finanziert wurde sie durch die institutionelle Förderung des Ministeriums für Kultur der Tschechischen Republik zur langfristigen konzeptionellen Entwicklung der Forschungsorganisation Nationales Denkmalamt.

Mgr. Zdeněk Schenk, Ph.D., Muzeum Komenského v Přerově, p. o., Horní náměstí 7/7, Přerov I - Město, 75002 Přerov, Česká republika, schenk@prerovmuzeum.cz

PhDr. Zdeněk Vácha, Národní památkový ústav, územní odborné pracoviště v Brně, nám. Svobody 8 , 60154 Brno, Česká republika, vacha.zdenek@npu.cz

Radim Vrla, Národní památkový ústav, územní odborné pracoviště v Kroměříži, Riegrovo náměstí 3228/22, 76701 Kroměříž, Česká republika,vrla.radim@npu.cz 
